International Journal of Multidisciplinary Research AND ANALysis

ISSN(print): 2643-9840, ISSN(online): 2643-9875

Volume 04 Issue 05 May 2021

DOI: 10.47191/ijmra/v4-i5-18, Impact Factor: 6.072

Page No.- 614-620

\title{
Historical and Pedagogical Requirements for the Qualifications of a Higher School Teacher
}

\author{
Shoira Abdumajitovna Abdujalilova \\ Candidate of Pedagogical Sciences, Associate Professor Chirchik State Pedagogical Institute Tashkent, Uzbekistan
}

ABSTRACT: The article examines the development of higher education in Uzbekistan in the era of the third Renaissance in accordance with international standards, based on the effectiveness of the teacher of higher education. Qualification requirements for higher education teachers and methodological bases of their formation are studied. Theoretical features of the qualification requirements for teachers of higher education and their issues of teacher-student tradition and distance learning methods are analyzed on the basis of educational regulations, pedagogical heritage and scientific and pedagogical research.

KEYWORDS: system, education, training, lessons, training, methodology, economics, banking, finance, production, marketing, Teacher, student, distance learning, historical heritage, kindness, knowledge, devotion, patience, tolerance.

\section{INTRODUCTION}

The ordinance of the President of the Republic of Uzbekistan dated November 6, 2020 "On measures for the development of education and science in a new period of development of Uzbekistan" sets the task of studying the pedagogical heritage from a new point of view. In this regard, the study of historical and pedagogical requirements for the qualification of higher education teachers remains relevant.

The set of professional, ethical and social requirements for teachers in the Uzbek pedagogical heritage is based on the needs of each period. Here we draw your attention to the analysis of the system of qualification requirements for teacher qualifications.

In the history of Uzbek pedagogy, the system of teaching and educating people was unique. The main aspects of this system are as follows:

- The person who teaches and educates is specially trained by the Master;

- The person who teaches and educates is individually trained in the study of folk pedagogy;

- Prepared by educators and educators by religious scholars working in religious churches;

- Later, in the Middle Ages, educators were trained through madrassas.

In this system, educators and educators are adequately trained, and in many cases they are engaged individually with educators. In the 15th century, Mirzo Ulugbek built a madrasah in Samarkand to train teachers. Such preparation is based on the following:

a) teachers of exact and natural sciences;

b) teachers of religious sciences;

c) teachers of jurisprudence.

This novelty of Mirzo Ulugbek was accepted in madrassas of our country and educators were trained in accordance with the needs of each period.

\section{THE MAIN FINDINGS AND RESULTS}

Abdurauf Fitrat in his work "Debates" analyzes the crisis of education in our country at the beginning of the twentieth century. According to him, the crisis was caused by the following:

\footnotetext{
- Loss of science in the teaching process;

- Outdated teaching methods;

- Decreased professionalism of educators.
} 


\section{Historical and Pedagogical Requirements for the Qualifications of a Higher School Teacher}

Therefore, at the beginning of the last century, there was a shortage of teachers in higher education institutions (madrasas) of the country.

Since the 1930s, the training of teachers of higher education in the direction of the Uzbek pedagogical school of the present SamSU has been organized. European standards of teaching are adopted.

At the same time, attention is paid to teaching talented Uzbek youth in foreign universities. For example, 13 swallows who studied at the University of Berlin in Germany will grow up, that is, 13 scientists such as Kori Niyazi and Vahid Zakhidov.

In our country, since the 1940s, the training of teachers in all areas of higher education has been established. It is based on standard-based education.

During the years of independence, the training of higher education teachers in all areas has been resumed in Uzbekistan.

All this shows that the training of higher education and educators in our country is of a regular nature. At the same time, over the centuries, the requirements for the qualification of higher education teachers have been formed, and they have come down to us as a means of our pedagogical heritage.

There are higher education institutions in Uzbekistan in several areas. The basics of these directions are as follows:

- economics and banking and finance;

- production and marketing;

- entrepreneurship and health;

- direction of education and art, etc.

Higher education institutions in this area need a teacher of higher education with their own specialization. At the same time, teachers of higher education institutions in different areas are united in one goal with the following aspects:

1) have theoretical knowledge on the basics of education and upbringing;

2) knowledge of the didactic basis of teaching;

3) have the competence to impart knowledge and education;

4) determine the prospects of their industry.

The foundations of these common features are reflected in our historical and pedagogical heritage. Therefore, the historical and pedagogical requirements are based on the resource basis for the qualification of a higher education teacher.

The thinker Yusuf Hos Hajib (11th century) described the set of requirements for the future of the teacher's malas based on the needs of his time [10]. It is based on the experience of Turkish pedagogy in this regard and the requirements for education in the Holy Quran. In his opinion, a teacher engaged in the education of the younger generation must meet the following requirements:

- to be formed by the idea of goodness;

- acquire knowledge in accordance with the needs of the time;

- be equipped with the skills of education and upbringing;

- adhere to the principle of good deeds.

It should be noted that the thinker set specific qualification requirements for teachers a thousand years ago. The requirements of Kindness, Knowledge, Practice and Activity play an important role in it. In this, Goodness is an idea, which is the basis for shaping the teacher's worldview;

Knowledge is the basis of a teacher's professional activity; Internship means that the teacher is effective in his / her professional activity, and Activity means that the teacher is dedicated to his / her profession. We take these requirements as a set of compensations in modern parlance.

During the time of Yusuf Hos Hajib, the educators of the individual were trained through a special Master.

The focus is on knowledge. According to the thinker, "God created man, gave him a profession, knowledge and training". In this sense, education is a profession, for which a person must master Knowledge and Learning. We take this approach as a requirement for teacher qualification, which was stated a thousand years ago. Note (Figure 1) 


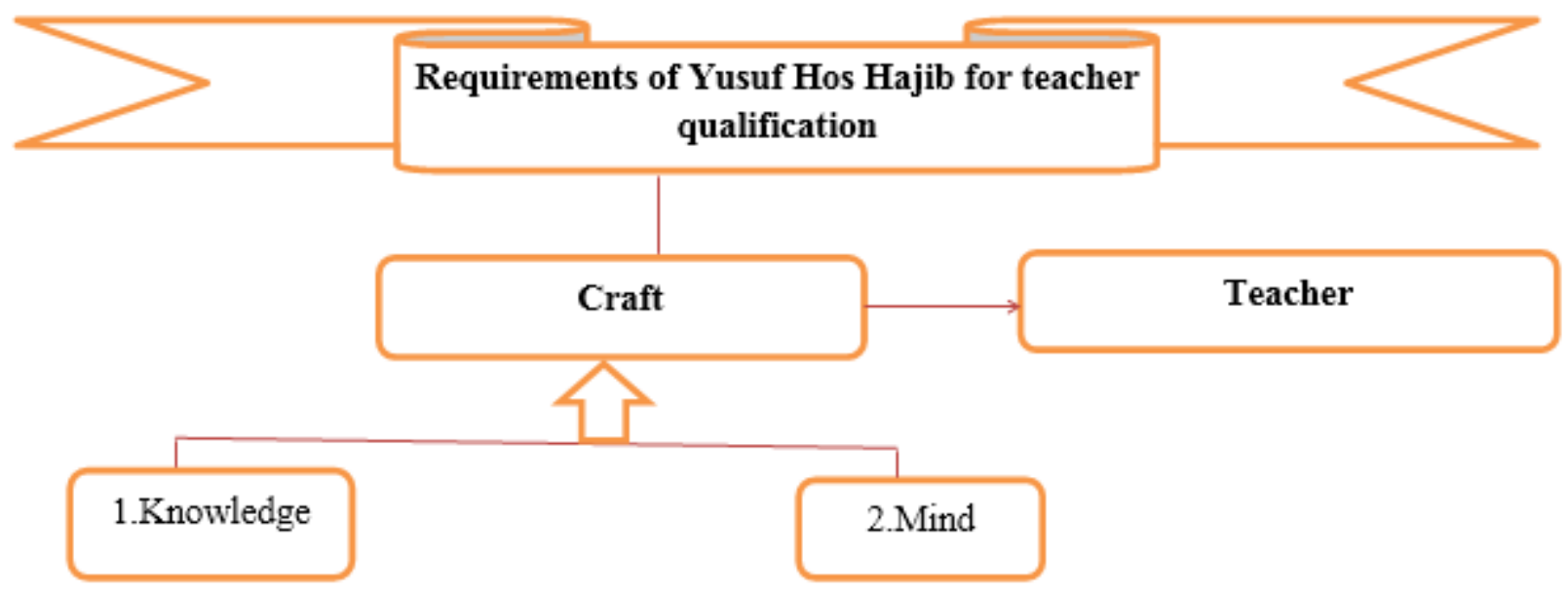

This concept of Yusuf Hos Hajib is unique and has not lost its relevance today. According to him, "Knowledge is the source of happiness, and ignorance is unhappiness. In order to acquire knowledge, a person must be educated". It also says the thinker:

I spoke to the heroes,
I distorted the meaning of my word.

Therefore, the requirement of Yusuf Hos Hajib to be a teacher should be accepted within the framework of Knowledge and its basis is Education. We take this Learning Concept as a skill to be consumed today.

Yusuf Hos Hajib recommends that a person master the work of education until the age of 30. According to him, a person enters the age of old age after the age of 60 , and during this period he should be engaged in transmitting his experiences to the younger generation. This means that a thousand years ago, a person was engaged in education until the age of 30 in order to engage in education.

Five hundred years later, Alisher Navoi's friend Hussein Voiz Kashifi (15th century) in his work Futuvvatnomai Sultani (Program of Heroes) reflects on the requirements for teacher qualifications based on the needs of his time [11] According to him, the younger generation will need education and upbringing, so there will be a need for a special Master.

Kashifi makes several demands on those engaged in Mentoring (teaching). There are twenty of these requirements, and they are as follows:

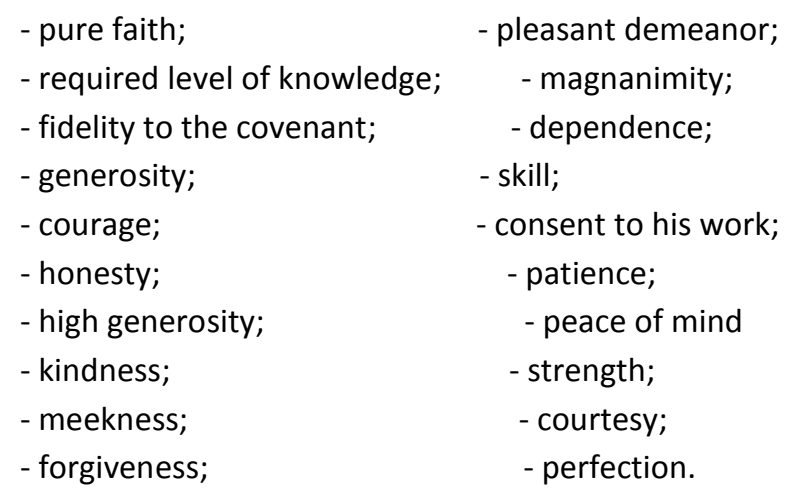

It is noteworthy that five hundred years ago, Kashifi created a unique professional profile of the teaching profession. In his time, a person who met these requirements was engaged in educational work, hence they were called Masters.

According to the thinker, a teacher must have the following skills:
1) be enlightened;
2) be prudent;
3) be mentally mature;
4) to be free;
5) be sincere;
6) be honest;
7) be compassionate. 


\section{Historical and Pedagogical Requirements for the Qualifications of a Higher School Teacher}

It is worth noting that this set of skills has not lost its relevance today. According to Kashifi, the Teacher should always be ready for the following:

a) relieve the student's worries;

b) follow the rules given to the student;

c) winter protection of students in all conditions;

d) not to interfere with the property of his students.

It should be noted that these approaches of the thinker are also relevant for today's teachers. Note the views of Kashifi in general (Figure 2):

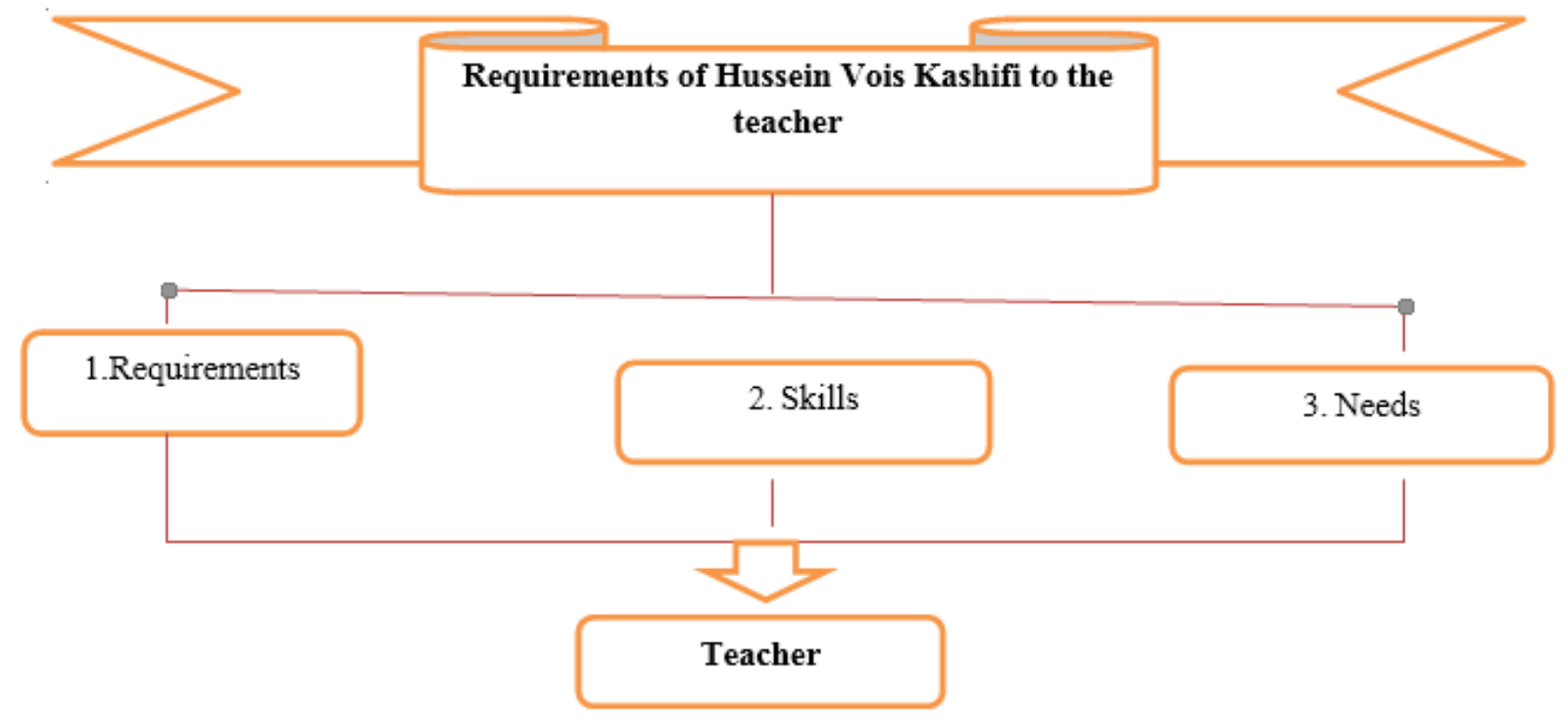

Thus, it would be appropriate to use Hussein Vois Kashifi's requirements for teacher qualification today.

Five hundred years after Kashifi, the first Uzbek professor, Abdurauf Fitrat (20th century), reflected on the requirements for teachers' qualifications in the age of the Leader of Salvation [12.62-207]. His approaches are of a scientific and pedagogical nature, according to which the teacher should have the following skills:

1) self-knowledge;

2) acquisition of knowledge;

3) be moral.

Fitrat refers to the development of a person's mind when it comes to self-knowledge. By mastering knowledge, he means the study of the sciences of Tafsir, Hadith, Fiqh, Theology, History, Linguistics, Geography, Medicine, Chemistry, Natural Science, Nabodat, Creature, Cultural Studies, Accounting, Jabr, Handasa, Hayat, Spirit, Morality, Theology and Logic. When he says to be moral, he means to acquire the highest qualities such as courage, kindness, generosity.

It is noteworthy that Fitrat's approach emphasizes the qualifications of science teachers. In this respect, we take Fitrat's approaches as a unique concept. Note (Figure 3)
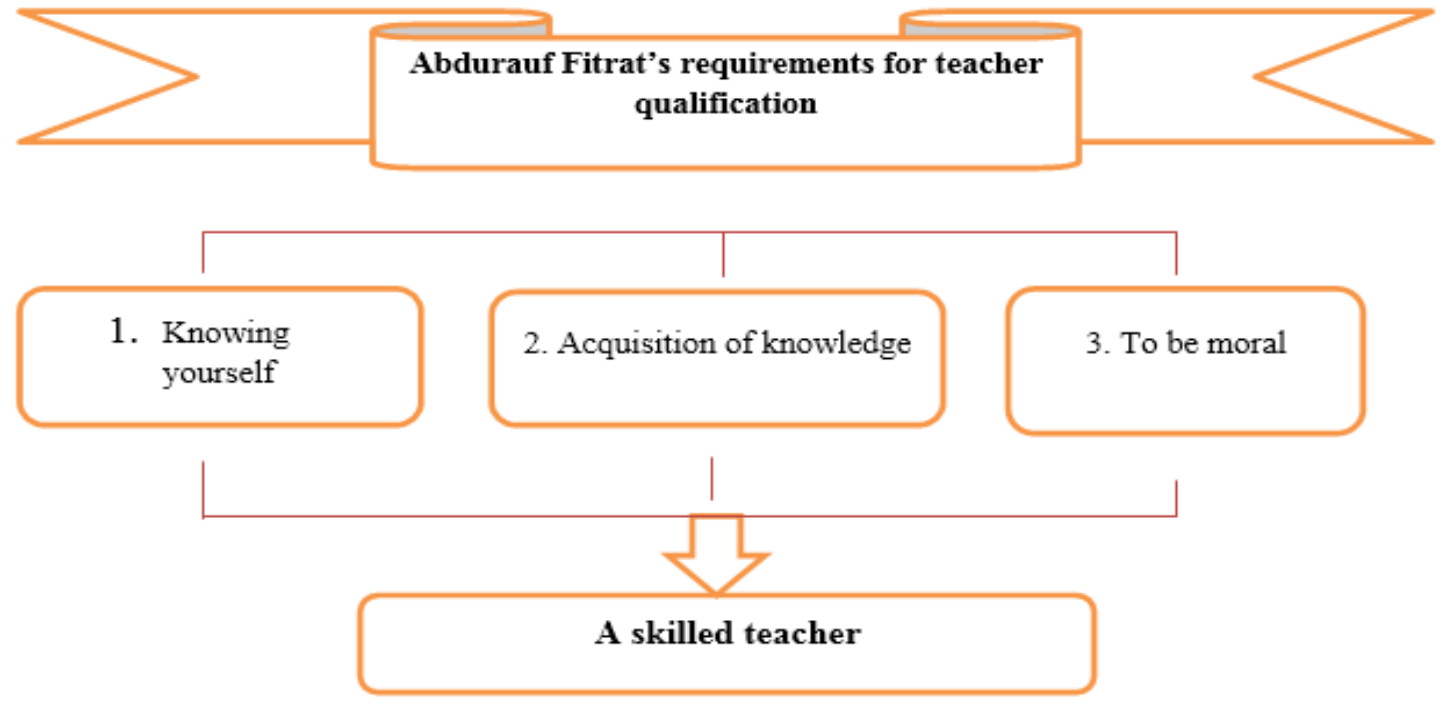


\section{Historical and Pedagogical Requirements for the Qualifications of a Higher School Teacher}

In the history of pedagogy of the peoples of the world, the requirements for the qualification of teachers have been gradually described. Here we draw your attention to the most important.

The Czech pedagogue Jan Amos Comenius (17th century) in his book The Great Didactics developed a set of requirements for the qualification of teachers. First of all, he says, "Most teachers don't know how to teach, and as a result they have a hard time doing their homework" [13.11-105]. "Great didactics is the art of teaching everything to everyone," he said. In this sense, teaching is a unique art of teaching in which the teacher must act as an actor.

Comenius sets the following requirements for the qualifications of teachers:

1) be polite and kind;

2) have specific behaviors;

3) treat students with respect;

4) deep knowledge of their subject.

These requirements have been accepted as a novelty in Western pedagogy. Because they have a drawing on the image of the teacher. According to the thinker, the teacher must strictly adhere to the natural method of his activity.

According to Comenius's approach, the teacher must adhere to strict discipline. He says: "There is a saying in the Czechs: A school without discipline is a bath without water. Therefore, the discipline of the teacher is the basis of the discipline of the school. A teacher should never shout, brag or look down on students at school". It should be noted that these requirements are still relevant today. Note (Figure 4):

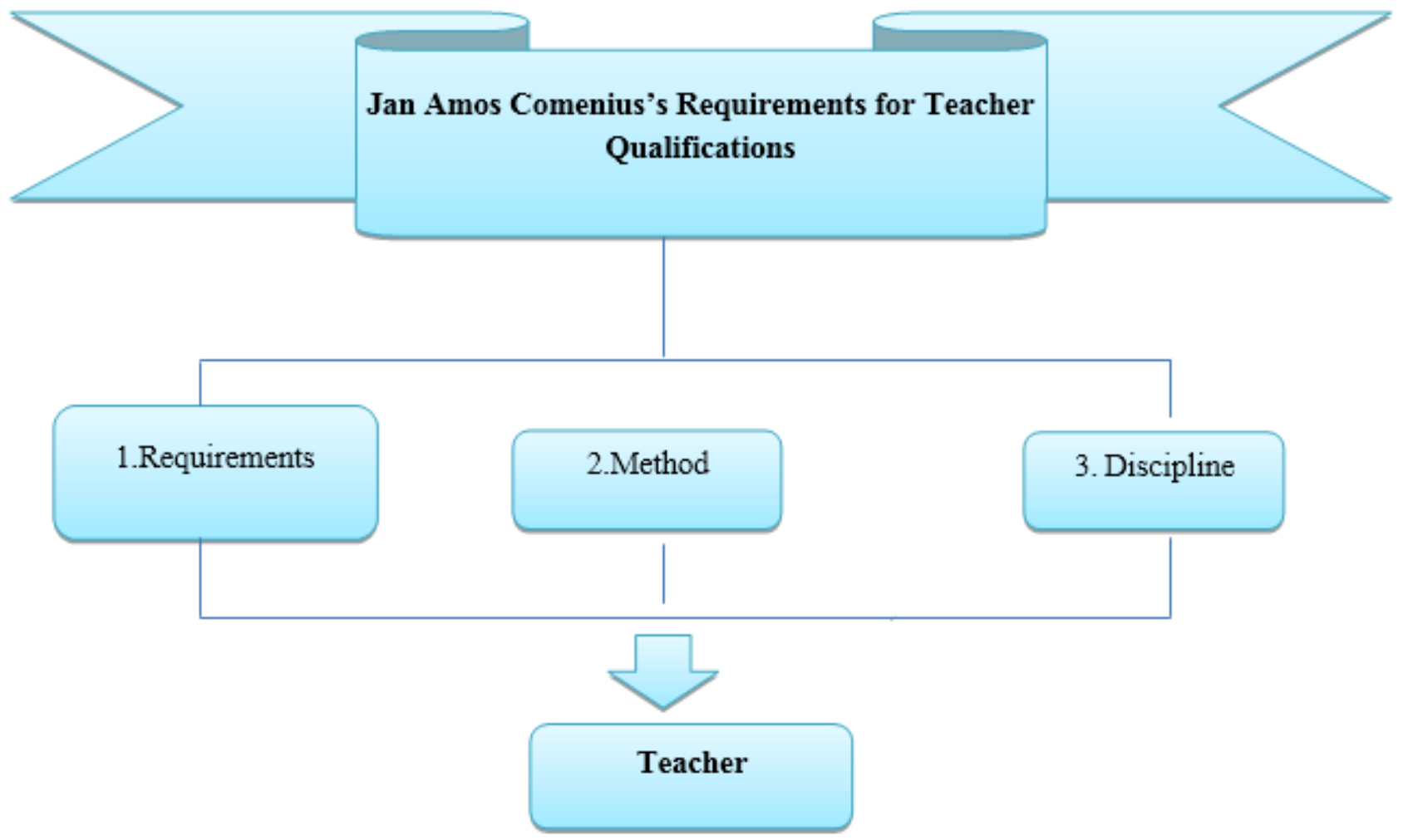

The French educator Jean-Jacques Russo (18th century) in his book On Emile or Upbringing systematized the requirements for the qualification of a teacher [14. 199-297]. In his view, the basis of a teacher's qualification is reflection and observation. At the same time, the teacher should approach each lesson with a new way of thinking and monitor the students' mastery. He says, "If a person was born strong and mature, he would not need upbringing. That's why a teacher's job is to make a person strong and mature".

Russo was the first in the history of pedagogy to substantiate the issue of social education. According to him, a person should meet the needs of his family, teammates and society. "Fathers," he says, "must raise their children as individuals who benefit society and the state". This means that the teacher must treat the students as fathers. It should be noted that Russo's requirements for teachers' qualifications are as follows:
a) humanity;
b) wisdom
c) morality;
g) obligation. 
These requirements have been accepted by modern Western pedagogy. The following wisdom of Russo is known all over the world: "Respect the children and refrain from foolishly discussing their shortcomings!"

In this regard, childcare is one of the main principles in Russo's requirements for teacher qualifications.

Rousseau defined the individual task of students as making each individual a member of society. He says: "Society doesn't need Rabynson Cruises, and teachers have to take responsibility for that". Thus Russo set out the following rules for teachers:

$$
\begin{aligned}
& \text { - tolerance; } \\
& \text { - patience; } \\
& \text { - kindness. }
\end{aligned}
$$

It should be noted that these rules have not lost their relevance today. Note (Figure 5):

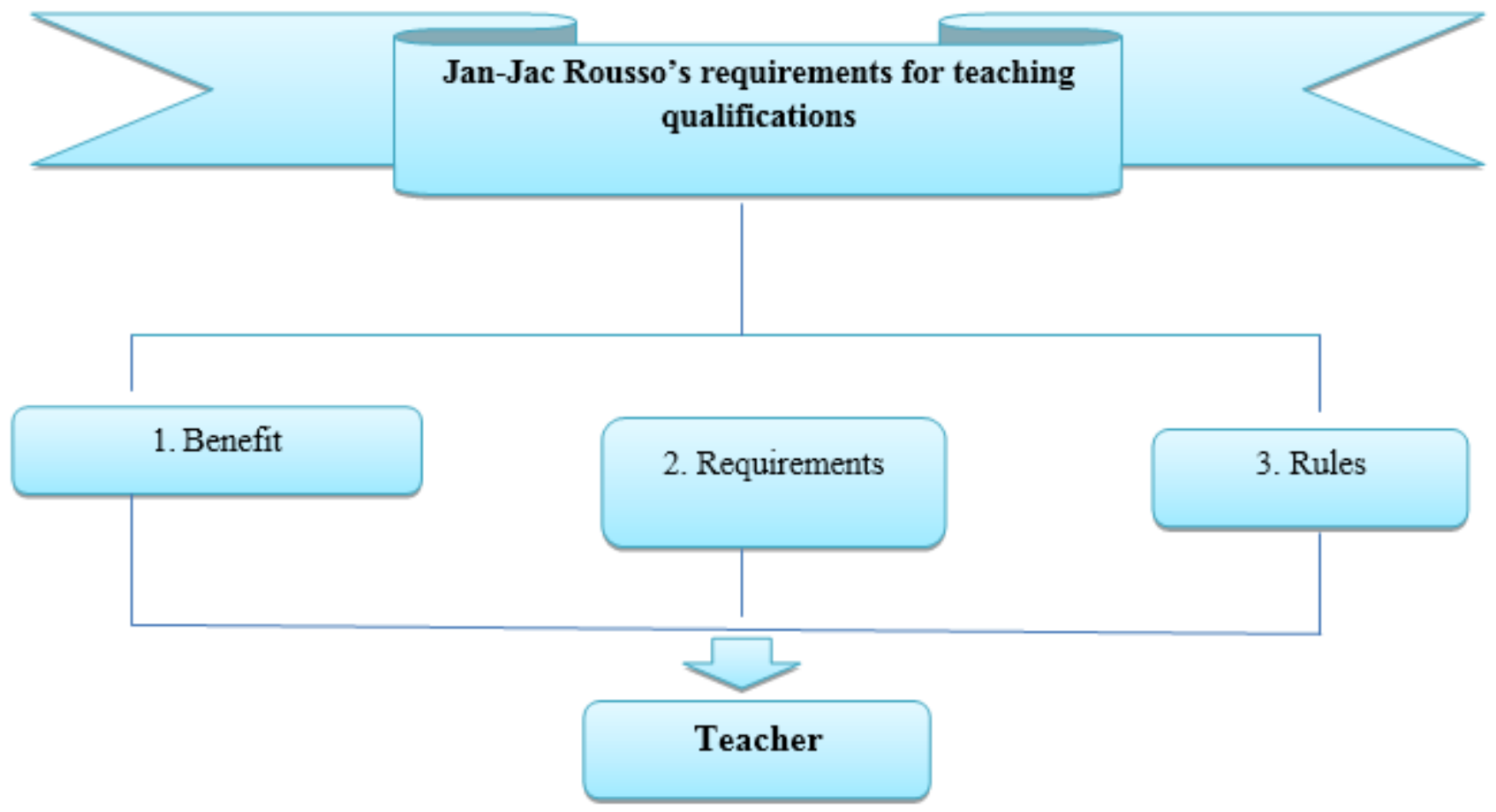

The views of the Swedish pedagogue Johann Henryk Pestalozzi (19th century) play an important role in the issue of teacher qualification [15. 312-322]. He was the first to use the concept of "public education" in Public Education and Industry, arguing that primary education should be free. It is this approach that forms the basis of his teacher qualification requirements.

\section{CONCLUSION}

Pestalozzi's requirements for teacher qualifications are as follows:
a) education of boys and girls;
b) providing primary education for all;
c) rely on the easiest methods;
g) make everyone literate.

These demands of the thinker are accepted throughout the education system. His idea of teachers relying on simple methods is especially popular. According to Pestalozzi, the teacher must be mature in the following respects:

- mental;

- physical;

- moral.

"Europe's mentally, physically and morally mature teachers will save," he says. This approach is still relevant today. Note (Figure 6): 


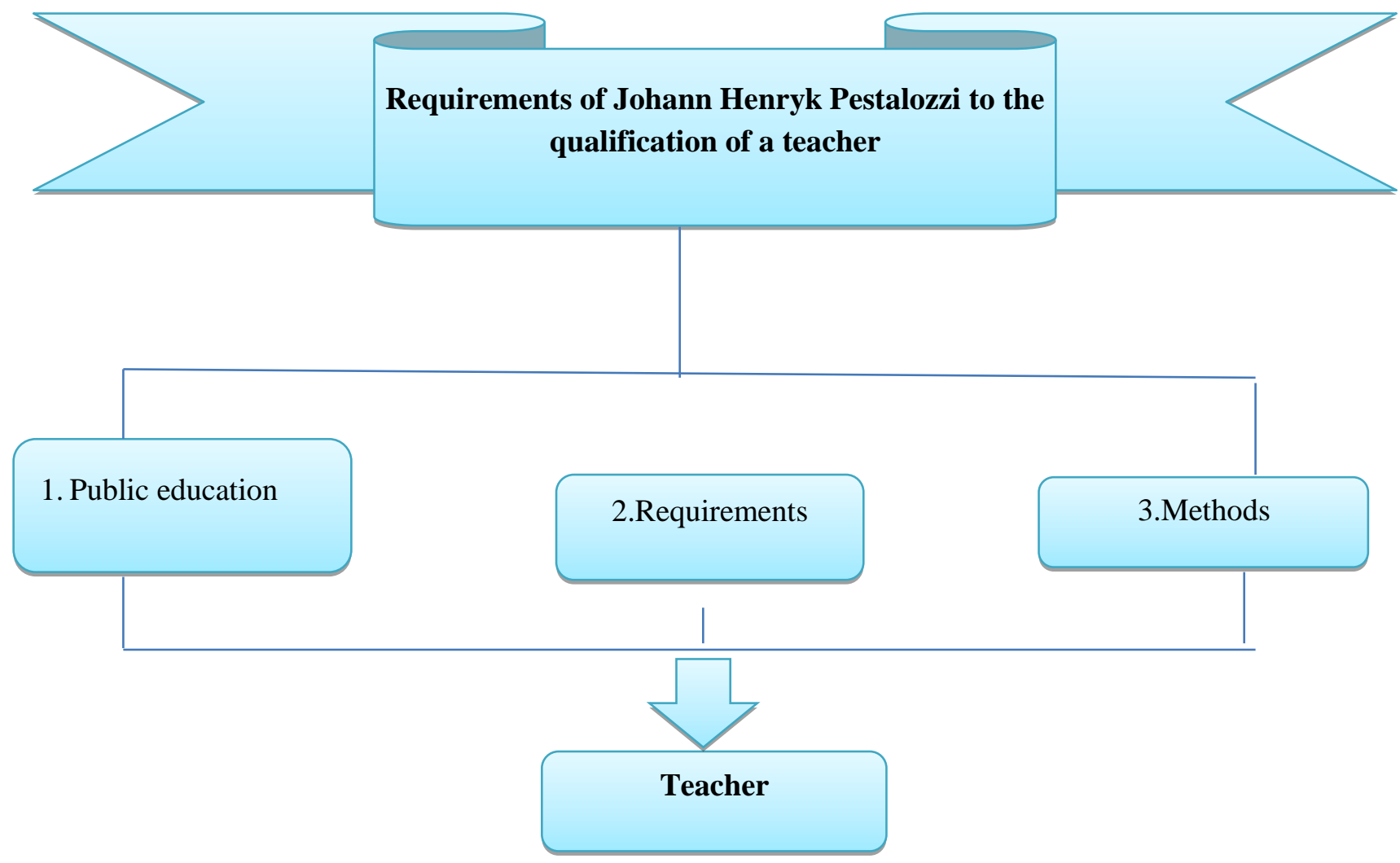

Thus, in the history of our national pedagogy and pedagogy of the peoples of the world for centuries, based on the needs of each period, clear and understandable requirements have been set for the qualifications of teachers. It would be expedient for this issue to be understood by future teachers.

\section{REFERENCES}

1) Begimqulov U.Sh. Scientific and theoretical bases of introduction of modern information technologies in pedagogical education. Tashkent: "Science".2007

2) Bregeda I.D., Grushevskiy S.P., Krymskaya E.B. Synthesis of pedagogical and information technologies in distance learning // Newsletter, 18, 2003. -pp.-74-76

3) Jumaboev S.M. Procedure for teaching and using Delpi programming language // Physics, mathematics, computer science. - Tashkent:.2017.№5, -pp.59-64.

4) Mardonov Sh.Q. Technology for the development of electronic modular didactic support in pedagogy.-Tashkent: "Reliable partner".2021, -pp.54-60.

5) Rysyukova Yu.V., Zakirova F.M. Scientific and methodological web-activity and its formation among students of the direction "Professional education". Methodical instructions. Tashkent: Alokachi,2012. -p-56.

6) Safarova R.G. and b. Didactic approaches to the selection of educational material in the age of the principle of concentrism. Tashkent: Science and technology, 2012.-p. 72

7) Abdujalilova Sh. Abdurauf Fitrat's views on family upbringing. NDA. Tashkent:,2002.

8) Axrorova D. Enlightenment-pedagogical views of Abdurauf Fitrat. NDA. Tashkent:, 1998.

9) Qosimov B. National Awakening: Courage, Devotion, Perseverance. -Tashkent: "Spirituality". 2002. p.9.

10) Yusuf Hos Khojib. Qutadgu bilig.-Tashkent: "Science" .1991 All excerpts are taken from this source.

11) Hussein Vois Kashifi Futuvvatnomai Sultoniy. Tashkent: 1994. Extracts are taken from this source.

12) Abdurauf Fitrat.Selected works.5-volume Tashkent:,2010. -pp. 62-207.

13) Komensky Ya.A. Great didactics // Pedagogical heritage.-Moscow: "Pedagogy".1989. -pp. 11-105.

14) Rousseau J.J. Emil. // Pedagogical heritage. -Moscow: “Pedagogy".1989. -pp. 199-297.

15) Pestalozzi I.G. On public education and industry // Pedagogical heritage.-Moscow: “Pedagogy”.1989. -pp. 312-322. 